Creative commons User License: CC BY-NC-ND

Abstracted by: EBSCOhost, Electronic Journals Service (EJS),

Google Scholar, Journal Seek, Scientific Commons,

Food and Agricultural Organization (FAO), CABI and Scopus

http://www.ajol.info/index.php/jae
Journal of Agricultural Extension

Vol. 22 (3) October, 2018

ISSN(e): 24086851; ISSN(Print); 1119944X

http://journal.aesonnigeria.org

Email: editorinchief@aesonnigeria.org

\title{
Welfare Status of Rice Farming Household in Office du Niger Segou Region of Mali \\ https://dx.doi.org/10.4314/jae.v22i3.7
}

Ballo, Mamadou,

Experts Group for Sustainable Development,

Hamdallaye $\mathrm{ACl} 2000$,

Bamako Mali.

amadouballo@07gmail.com; +22379158375

Olutegbe, Nathaniel. S.

Department of Agricultural Extension and Rural Development

University of Ibadan, Ibadan

siii004u@yahoo.com; 07032077856

\section{Adekoya, Adegbenga. E.}

Department of Agricultural Extension and Rural Development

University of Ibadan, Ibadan

vichenfel2@yahoo.com; 08038209063

\section{Abstract}

The study examined the welfare status of rice farming household in Office du Niger, Segou region, Mali. Multi-stage sampling was used to select 137 rice technology adopters and 65 non-adopters in the study area. Frequency counts, percentages, PPPMC and t-test were used for data analysis. About $45.0 \%$ of non-adopters and $29.2 \%$ of adopters were aged 31-40. Non-adopters and adopters had an average of 6 and 10 years of experience in rice farming, respectively. Most adopters (73.0 \%) and non-adopters (50.8\%) had a farm size between 1-5 hectares. Most adopted rice varieties were Kogoni 91-1 (94.2\%) and IR 32 mille (81.0\%). There was a high level of adoption among $59.1 \%$ of adopters. About $61.0 \%$ of adopters, but $53.8 \%$ of non-adopters earned less than 500,000 CFA (864.30 USD) annually from other activities as against between 500,000 and 1,000,000 CFA (872.60 and 1,745.20 USD) among $58.5 \%$ of non-adopters and above 2,000,000 CFA (3,490.40 USD) for $67.2 \%$ of adopters. The majority (61.5\%) of non-adopters had improved welfare status as against $80.3 \%$ of adopters in the same category. Household size $(r=0.192)$, income gained from rice production $(r=0.482, p=0.000)$ significantly influenced respondents' welfare level. There was a significant $(t=-$ 12.089) difference in quantity of rice produced by adopters

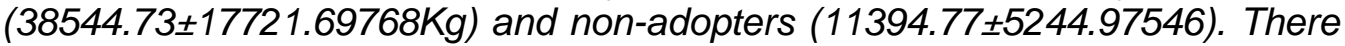
was a significant $(t=-2.917)$ difference) in welfare status of the adopters' and non-adopters. Office du Niger should intensify efforts at up-scaling dissemination of improved rice technologies to cover more rice farmers.

\section{Keywords: Rice farming, rice technology, household welfare status}


Creative commons User License: CC BY-NC-ND

Abstracted by: EBSCOhost, Electronic Journals Service (EJS), Google Scholar, Journal Seek, Scientific Commons,

Food and Agricultural Organization (FAO), CABI and Scopus
Journal of Agricultural Extension

Vol. 22 (3) October, 2018

ISSN(e): 24086851; ISSN(Print); 1119944X

http://journal.aesonnigeria.org

http://www.aiol.info/index.phpliae

Email: editorinchief@aesonnigeria.org

\section{Introduction}

Among the world 's extremely poor people, 75 percent live in rural areas, and for the most part they depend on agriculture, forestry, fisheries and related activities for survival (Gustavo and Kostas 2007). The promotion of the rural economy in a sustainable way became one of the priorities of most countries development policy across the world. This is aimed at achieving the global society's stated objectives on hunger and poverty reduction. According to West Africa Agricultural Productivity Programme (WAAPP, 2014), agriculture as a sector provides the source of livelihoods for almost two-thirds of the population in the continent. Many agricultural development programmes were therefore initiated to boost food production at international level, making agricultural sector the key to the development with a view to bringing about high poverty reduction impact to the majority of the population.

Rice is one of the most important staple foods in the world which is widely consumed by a large part of the world's human population. According to The Food and Agriculture Organization Corporate Statistical Database, FAOSTAT (2012) and supported by Omics International (2014), it is the agricultural commodity with the third-highest worldwide production, after sugarcane and maize. Research has shown that it has a key role to play in global poverty alleviation. Dawe (2000) revealed that the rice research contributes to poverty alleviation through several pathways, and these contributions benefit both producers and consumers. The direct pathway leads to higher productivity and higher profits for farmers. The indirect pathway arises from the lower prices for consumers that are the inevitable result of higher farm productivity for any given level of demand.

However, available statistics has shown that rice production has assumed a declining trend in recent years, with widening gap between demand and production. African Development Bank Group (2014) decried that one-third of the world rice is imported each year, about 20\% (5.2 million tons) for West Africa alone. The African Development Bank Group (2014)'s analysis shows that by 2020, an extra 17 million tons milled rice, costing billions in scarce foreign currency, will be required if domestic production continues to lag behind the growing demand. This implies that the food security, especially in poor households, where sizable portion (20-25\%) of their revenue is spent on food, could be adversely affected by slight price increase in the international rice market. Faced with this critical situation, the need to make decision in order to mitigate the impact of increased world rice price on Africa development was very necessary.

The specific situation in Mali is not any different. Agriculture, being the mainstay of economy, rice alone contributes around 5\% of the country's GDP (Baris, Zaslavsky, and Perrin, 2005). Rice consumption has increased in a fast manner. According to the budget/consumption survey conducted in 2006 and noted by Minister of Agriculture of Mali (2009), consumption per head in the country stood at around 57 $\mathrm{kg} /$ inhabitant/year, making rice the foremost cereal consumed in urban areas. Ironically, Malian agriculture has been strongly affected by the difficult agro-climatic conditions which have put domestic rice production and its potential in meeting future demands under threats. This has brought about a mismatch between local production 
Creative commons User License: CC BY-NC-ND

Abstracted by: EBSCOhost, Electronic Journals Service (EJS), Google Scholar, Journal Seek, Scientific Commons,

Food and Agricultural Organization (FAO), CABI and Scopus
Journal of Agricultural Extension

Vol. 22 (3) October, 2018

ISSN(e): 24086851; ISSN(Print); 1119944X

http://journal.aesonnigeria.org

http://www.ajol.info/index.php/iae

Email: editorinchief@aesonnigeria.org

and demand, with more than half of the consumption being taken care of by importation.

In an attempt to respond to this continued low rice production trend in Mali, the country's ministry of agriculture facilitated the development of new agricultural technologies in order to enhance rice production for possible adoption in a sustainable manner. In order to achieve this, Mali's agricultural policies planned to involve all systems of rice production as well as intensify activities among the stakeholders. Essentially, the policies were aimed at involving the sustainable extension of cultivated areas and the use of appropriate technologies, including improved varieties, crop techniques, pest control and fertilization. These also included the construction of new agricultural water management schemes to promote rice double-cropping and off-season market gardening. It also includes the development of rain fed rice growing through large-scale distribution of New Rice for Africa (NERICA) varieties in areas with annual rainfall at or above $800 \mathrm{~mm}$.

These actions according to Mali's minister of agriculture, (2013, 2014, 2015, and 2016) led to increase in rice production, which has gone up from 1,189,130 tons in 2012-2013 agricultural campaign to 2,451,321 tons in 2015-2016 campaign. The increased production also implies a reduction in the quantity of rice being imported into Mali. This has led to increased domestic production, thereby lowering annual imports to only 100,000 tones (World Grain, 2016). However, the technical performances of an agricultural technology have been argued as not sufficient to prove its impact on the adopters' economic performance.

Fred (2015) observed that productivity should translate to improved welfare of households which includes meeting needs such as education, health, housing, production factors, transport, among others. Unfortunately, poverty situation has only improved marginally in Mali, with little or no study at all establishing any nexus between this little improvement with improved rice productivity, focusing on its farmers. Interestingly, today's development debate focuses on rural development and poverty reduction, an important question remains the relationship between agriculture development and farmers' welfare. Therefore, although adoption of rice technologies has brought about significant improvement on yield and overall rice production as reported by a number of studies (Minister of agriculture of Mali, 2009, 2013, 2014, 2015; and World Grain, 2016among others), it is equally, if not more, important to ascertain the extent to which this has translated to improved (or even otherwise) welfare of rice farming households. There is however dearth of information establishing a link between Office du Niger rice productivity and farmers' household welfare. This study was thus carried out to examine the contribution of Office du Niger rice technology adoption to rice faming household welfare, providing answers to the following research questions:

What are the socio economic characteristics of respondents?

What is the level of adoption of the rice technologies?

What is the level of rice production? 
What is the welfare status of rice farming households?

\section{Hypotheses of the study}

$\mathrm{H}_{01}$ : there is no significant relationship between the level of adoption of rice technologies and household welfare status.

$\mathrm{H}_{02}$ : there is no significant relationship between level of rice production and welfare status of rice farming households.

H03: There is no significant difference in the quantity of rice produced by adopters and non-adopters of rice technology.

H04: There is no significant difference in the household welfare status of adopters and non-adopters of rice technology.

\section{Methodology}

The study was carried out in Segou region which is an administrative region in Mali, situated in the center of the country with an area of $64,821 \mathrm{~km} 2$ (around $5 \%$ of Mali). The region is bordered by Sikasso region on the south, Tombouctou and Mopti on the east, Burkina Faso to the southeast and the Koulikoro region to the west. In 2009 it had 2,336,255 inhabitants, making it the second most populous region of Mali according to Malian general population and habitat census provisory results in 2009. Its administrative capital is the town of Segou. The Segou region is characterized by a semi-arid climate and irrigated by two important waterways. The Office du Niger is situated in the Ségou region in the fertile Niger delta. It accounts for about $56 \%$ of total rice production in the country (Minister of agriculture of Mali, 2013).

Data were collected from all registered rice producers in Office du Niger area who have adopted the rice technologies disseminated, with the aid of a well-structured interview schedule. Information was also obtained from non-adopters of Office du Niger rice technologies to serve as control for assessing effects of the technology on production and welfare of farming households. Both categories of respondents were sampled using multi-stage sampling procedure.

The Office du Niger is divided into seven (7) zones (Niono, Molodo, N'Debougou, Kouroumari, M'bewani, Ke-Macina and Koroungo) according to Office du Niger 20162017 campaign plan. The first stage involved a random selection of forty percent $(40 \%)$ of the total zones in the study area. These include M'bawani, N'debougou, and Molodo. In the second stage, two (2) villages in each selected zone were purposively selected due to their higher prevalence of rice production, to make six (6) villages. Third stage involved a random selection of ten percent (10\%) of respondents among registered rice farmers in each of the selected village as the sample for the study. This gave a sample size of 137 respondents. For the selection of non-adopters, two (2) zones were purposively selected outside the Office du Niger zones as a control zone, also due to high prevalence of rice farming. These are Dougabougou and Doura. Two (2) villages were also purposively selected due to their high level of rice production within the area. Finally, ten (10) percent of non-adopters of technology among registered rice farmers were randomly selected from each selected village in 
Creative commons User License: CC BY-NC-ND

Abstracted by: EBSCOhost, Electronic Journals Service (EJS), Google Scholar, Journal Seek, Scientific Commons,

Food and Agricultural Organization (FAO), CABI and Scopus
Journal of Agricultural Extension

Vol. 22 (3) October, 2018

ISSN(e): 24086851; ISSN(Print); 1119944X

http://journal.aesonnigeria.org

http://www.ajol.info/index.php/iae

Email: editorinchief@aesonnigeria.org

the two zones to give a total of 65 non- adopters of technology. On the overall 202 respondents were sampled for the study.

The dependent variable of the study is the welfare status of the rice farming households. The variable was measured by asking the respondents to state the actual amount they spend on household basic items (such as food purchases, school fees, accommodation, utility bills, health etc.) on weekly basis. Per capita household expenditure was derived and the welfare categories were determined using After obtaining the welfare score for each household, a minimum score of 292000 CFA (504.75 USD), maximum welfare being 4480000 CFA (7,744.16 USD) while the mean score of 1203263 CFA (2,079.97 USD) were obtained. Using this score range, the welfare status of rice farmers was categorized into three groups of low, moderate and high using the mean and standard deviation values to determine benchmarks along the three welfare demarcations. The range of score therefore was 292000 to 637525.50 CFA (504.75 USD to $1,102.03$ USD) for low, 637525.51 to 1769000.48 CFA $(1,102.03$ to $3,057.91$ USD) for moderate and 1769000.48 to 448000 CFA $(3,057.91$ to 774.42 USD) for the high welfare category.

Other key variables of the study were quantity of rice produced and adoption of rice production technologies. Quantity of rice produced was measured by obtaining the quantity of rice produced over the past five production seasons. This information was provided by farmers using different measurement modules. However, the Kilogramme equivalent was used for each of the respondents. The average for these five-year period was used as the annual rice output. Adoption of rice technologies was measured by providing the farmers with a list of rice technologies disseminated for which they were to indicate adoption continuum. Farmers responded on a three-point scale of adopted and still using, adopted but abandoned, and not adopted. Respective scores of 2, 1 and 0 were assigned to these response options. Depending on the number of technologies to which adoption or otherwise was indicated, an adoption of rice production technology score was obtained and used for analysis. Both quantity of rice produced (in $\mathrm{Kg}$ ) and adoption (score) of rice technologies were categorized into high and low levels for each, using the mean score of 18.6 and $29808.36 \mathrm{Kg}$, respectively as the benchmark. The data for the study was analysed using the statistical packages and service solution (SPSS). Data were described using means, frequency distributions and percentages, Chi-square, PPMC and independent sample t-test.

\section{Results and Discussion}

\section{Socio-Economic Characteristics of Respondent}

Table 1 presents the result of socioeconomic characteristics of respondents. It shows that the majority $(80 \%)$ of non-adopters of rice technology and adopters $(93.4 \%)$ were males. The result further reveals that $44.6 \%$ of non-adopters and $29.2 \%$ of adopters were between the age group of 31 and 40 years, $24.6 \%$ of non-adopters and $24.8 \%$ of adopters were between 41 and 50 years. These findings clearly explain that the majority of the respondents fell within the economically active age, and thus agrees 
with Bob (2014) who reported that average age of farm workers is 40 versus 34 for non-farm workers. This implies that most of rice farmers were middle-aged. The research findings reveal that all non-adopters (100\%) were married, as against $92.7 \%$ of adopters in this category. The high proportion of the married could also suggest that rice production is a viable means of generating income for satisfying family basic needs. Result further informs that a large proportion (77.4\%) of adopters and nonadopters (73.8\%) had between 6 and 10 years of experience in rice production. This is an indication that both groups of respondents present a good proportion which has a wealth of experience in rice production. This is expected to have positive influence on their knowledge and skills acquisition capacity for improved rice productivity.

The study further reveals that most $(57.7 \%)$ adopters had no formal education while $17.5 \%$ had primary education. On the contrary, a large proportion $(73.8 \%)$ of nonadopters had no formal education. This result shows high level of illiteracy of rice farmers in the study area. The individual's formal education level can significantly shape his personality, including disposition towards agricultural technologies and hence adoption behaviour. This is in line with Sullumbe (2004) who reported that the level of formal education attained by an individual goes a long way in shaping his personality, attitude to life and adoption of new and improved practice.

The result further reveals that $87.6 \%$ of adopters are social group members against $72.3 \%$ of non-adopters. Most of rice producers are kept in close contact with others carrying out together in most of their activities within the community. More than half $(59.1 \%)$ of adopters of rice technology belonged to the Bambara ethnic group, while $20.4 \%$ are Foula (Peulh). About seventy-one percent and nine percent of nonadopters belonged in these respective groups. Other ethnic groups such as Bobo, Sonrhai, Belah Malinke and Belah were also represented in varying proportions. The result implies that all ethnic groups are living in cordial relationship among themselves. 
Creative commons User License: CC BY-NC-ND

Abstracted by: EBSCOhost, Electronic Journals Service (EJS), Google Scholar, Journal Seek, Scientific Commons,

Food and Agricultural Organization (FAO), CABI and Scopus
Journal of Agricultural Extension

Vol. 22 (3) October, 2018

ISSN(e): 24086851; ISSN(Print); 1119944X

http://journal.aesonnigeria.org

http://www.ajol.info/index.php/iae

Email: editorinchief@aesonnigeria.org

Table 1: Socio-economic characteristics of respondents

\begin{tabular}{|c|c|c|c|c|}
\hline \multirow{2}{*}{$\begin{array}{l}\text { Socio-economic } \\
\text { characteristic }\end{array}$} & \multirow{3}{*}{$\begin{array}{l}\text { Non-Adopters } \\
\%\end{array}$} & \multirow{2}{*}{ Mean } & \multicolumn{2}{|c|}{ Adopters } \\
\hline & & & $\%$ & Mean \\
\hline \multicolumn{4}{|l|}{ Age } & \\
\hline Less or equal 30 & 20.0 & & 15.3 & \\
\hline $31-40$ & 44.6 & $39.96 \pm 9.73$ & 29.2 & $45.02 \pm 12.9$ \\
\hline $41-50$ & 24.6 & & 24.8 & 1 \\
\hline $51-60$ & 7.7 & & 17.5 & \\
\hline $61-70$ & 1.5 & & 10.2 & \\
\hline Above 70 & 1.5 & & 2.9 & \\
\hline \multicolumn{5}{|l|}{ Sex } \\
\hline Male & 80 & & 93.4 & \\
\hline Female & 20 & & 6.6 & \\
\hline \multicolumn{5}{|l|}{ Religion } \\
\hline \multirow{2}{*}{\multicolumn{5}{|c|}{ Marital status }} \\
\hline & & & & \\
\hline Single & 0.0 & & 3.6 & \\
\hline Married & 100 & & 92.7 & \\
\hline Divorced & & & 0.7 & \\
\hline Widowed & & & 2.9 & \\
\hline $\begin{array}{l}\text { Membership of socio group } \\
\text { Farming experience in vear }\end{array}$ & 72.3 & & 87.6 & \\
\hline $1-5$ & 24.6 & & 19.7 & \\
\hline $6-10$ & 73.8 & $7.22 \pm 2.56$ & 77.4 & $7.89 \pm 2.21$ \\
\hline $11-15$ & 0.0 & & 2.9 & \\
\hline $16-20$ & 1.5 & & 0.0 & \\
\hline \multicolumn{5}{|l|}{ Level of education } \\
\hline No formal education & 73.8 & & 57.7 & \\
\hline Adult education & 9.2 & & 14.6 & \\
\hline Primary education & 13.8 & & 17.5 & \\
\hline Secondary education & 3.1 & & 5.8 & \\
\hline Tertiary education & & & 4.4 & \\
\hline \multicolumn{5}{|l|}{ Ethnic group } \\
\hline Bambara & 70.8 & & 59.1 & \\
\hline Foula (Peulh) & 9.2 & & 20.4 & \\
\hline Sonrhai & 10.8 & & 1.5 & \\
\hline Others & 9.2 & & 18.9 & \\
\hline \multicolumn{5}{|l|}{ Household size } \\
\hline $1-10$ & 55.4 & $10.98 \pm 4.36$ & 47.4 & $13.84 \pm 7.95$ \\
\hline $11-20$ & 38.5 & & 37.2 & \\
\hline $21-30$ & 6.2 & & 12.4 & \\
\hline $31-40$ & 0.0 & & 2.2 & \\
\hline Above 40 & 0.0 & & 0.7 & \\
\hline
\end{tabular}

\section{Adopted Rice Technology}

The distribution of the respondents' based on the rice technology adopted is detailed in Table 2. It indicates that Adeny 11 and Kogoni 91-1, commonly called Gambiaka were the most adopted rice varieties by a large proportion $(94.2 \%)$ of rice farmers. Most of adopters (81.0\%) also adopted the variety IR 32,000 also called called Wassa. This variety was adopted but later abandoned by $15.3 \%$ of adopters of rice technology. The study further reveals that only a few proportion (5.8\%, $2.2 \%$ and 0.7 $\%$ ) adopted the varieties named BG, AD Nionoka and Watt 310 (Sambala malo), respectively. However, all (100\%) of them adopted the use of fertilizer, small spade for digging up weeds, and planting or sowing of seed. Close to the totality $(99.3 \%)$ of 
Creative commons User License: CC BY-NC-ND

Abstracted by: EBSCOhost, Electronic Journals Service (EJS), Google Scholar, Journal Seek, Scientific Commons,

Food and Agricultural Organization (FAO), CABI and Scopus
Journal of Agricultural Extension

Vol. 22 (3) October, 2018

ISSN(e): 24086851; ISSN(Print); 1119944X

http://journal.aesonnigeria.org

http://www.ajol.info/index.php/iae

Email: editorinchief@aesonnigeria.org

them also adopted the use of Huller and Cultivator (Motoculteur) and 95.6\% adopted the system of crop rotation.

The summary of the level of adoption among adopters is presented in Table 2. Using the mean adoption scores as the benchmark, respondents were categorized into high and low levels. The result reveals that $59.1 \%$ of rice farmers were categorized as high level adopters, with an adoption score of $\geq 18.69$, while $40.9 \%$ of rice technology adopters were categorised as low adopters. This implies that more than half of the respondents adopted rice technology at a high level. This agrees with Minister of agriculture's (2009) optimism as he had projected increase in rice yield as a result of anticipated high level of adoption of rice technologies which have been disseminated in the region.

Table 2: Adoption status of rice technologies

\begin{tabular}{lllll}
\hline Adopted rice technology & Not adopted (\%) & $\begin{array}{l}\text { Adopted and } \\
\text { Abandoned (\%) }\end{array}$ & Adopted (\%) & Mean \\
\hline Rice varieties & & & & \\
Adoption_Kogoni 91-1_Gambiaka & 0.7 & 5.1 & 94.2 & 1.93 \\
Adeny 11 & 0.7 & 5.1 & 94.2 & 1.93 \\
BG & 71.5 & 22.6 & 5.8 & 0.34 \\
AD Nionoka & 79.6 & 18.2 & 2.2 & 0.23 \\
IR 32 mille_Wassa & 3.6 & 15.3 & 81.0 & 1.77 \\
Watt 310_Sambala malo & 91.2 & 8.0 & 0.7 & 0.09 \\
Nerika L1 & 75.9 & 24.1 & 0.0 & 0.24 \\
Nerika L2 & 93.4 & 6.6 & 0.0 & 0.07 \\
Nerika 3 & 99.3 & 0.7 & 0.0 & 0.01 \\
Nerika 4_Gerekan malo & 100.0 & 0.0 & 0.0 & 0.00 \\
Rice-pisciculture & 100.0 & 0.0 & 0.0 & 0.00 \\
Huller & 0.7 & 0.0 & 99.3 & 1.99 \\
Infrastructure & & & & \\
Small dam for retaining water & 90.5 & 0.0 & 9.5 & 0.19 \\
Cultivator & 0.7 & 0.0 & 99.3 & 2.00 \\
Fertilizer & 0.0 & 0.0 & 100.0 & 2.00 \\
Sarcloir (small spade for digging up & & & & 2.00 \\
weeds) & 0.0 & 0.0 & 100.0 & \\
Replicage (planting, act of placing & & & 100.0 & 1.92 \\
into the ground), & 0.0 & 0.0 & 2.2 & 0.34 \\
Cultivation with intercalary & 87.6 & 10.2 & 95.6 & 1.77 \\
Crop rotation & 3.6 & 0.7 & &
\end{tabular}

\section{Income from Rice Production}

Table 3 shows that the majority of non-adopters earned between 500001 and 1000000FCFA. On the other hand, the majority of adopters (67.2\%) earned above 2000000FCFA. This is an indication that adopters of rice technologies earned higher level of income than their non-adopter's counterparts. This may be an indication that adoption of improved rice technology has helped farmers improve their productivity, through which they made more income. 
Table 3: Income generated from rice production

\begin{tabular}{lcc}
\hline Amount (FCFA) & Non - Adopters (\%) & Adopters (\%) \\
\hline$\leq 500,000$ & 18.5 & 0.7 \\
$500001-1000000$ & 58.5 & 5.8 \\
$1000001-1500000$ & 18.5 & 5.1 \\
$1500001-2000000$ & 4.6 & 21.2 \\
Above 2000000 & 0 & 67.2 \\
\hline
\end{tabular}

Source: Field survey (2017)

\section{Income from Other Sources}

Table 4 reveals the distribution of the income generated from other sources of revenue such as sorghum, millet, maize, tuber, vegetable, livestock and trade in the study area. The result reveals that $60.6 \%$ of adopters earned less than 500,000 CFA annually. However, $53.8 \%$ of non-adopters earned less than 500,000 CFA. This implies that most of the respondents practiced mixed cropping as a system of farming so as to increase their source of livelihood. It further reveals that rice farming was the main income source among both categories of rice farmers. This is consistent with Vandersypen, Keita, Coulibaly and Raes, Jamin (2007) that in Office du Niger, like other regions in Mali, farmers often supplement their income by growing vegetables on the fields in dry season.

Table 4: Income generated from other sources

\begin{tabular}{lcc}
\hline Amount (FCFA) & Non - Adopters (\%) & Adopters (\%) \\
\hline$\leq 500,000$ & 53.8 & 60.6 \\
500001 to 1000000 & 24.6 & 15.3 \\
1000001 to 1500000 & 13.8 & 4.4 \\
1500001 to 2000000 & 1.5 & 5.8 \\
Above 2000000 & 6.2 & 13.9 \\
Source: Field survey, & & \\
2017 & & \\
\hline
\end{tabular}

\section{Level of Rice Production Among Rice Farmers}

The result reveals that the minimum production score was $1575 \mathrm{~kg}$ and the maximum, $95499 \mathrm{~kg}$ while the mean is $29808.36 \mathrm{~kg}$. The mean was used to categorize the production score for rice technology adopters and non-adopters into high and low. The result shows us that $66.4 \%$ of adopters had high level of rice production as against the totality $(100 \%)$ of non-adopters who were low adopters for non-adopters with a mean score of less than $29808.36 \mathrm{Kg}$. This implies that there was a higher level of rice production among adopters than non-adopters. This is consistent with the finding of WAAPP (2014) which reported that the use of higher yielding rice varieties, adapted seed drill, more pest resistant tomatoes and other rice technologies help Malian farmers to increase production of different crop enterprises. 


\section{Welfare Status of Rice Farmers}

The study further shows the welfare status of adopters and non-adopters of rice technology in the study area. The result shows that $61.5 \%$ of non-adopters, but $80.3 \%$ of adopters had a high welfare status. This is an indication that rice production is a viable and profitable enterprise. Hence, rice production has a great potential of improving the welfare of farmers and the quality of their living standards in the study area. The result also affirms that improved rice technology has helped improve the welfare status of adopters, making them to have a high welfare status than their nonadopter counterparts.

\section{Relationship between Income from Rice Production and Farmers' Welfare Status}

The result of analysis further indicates that there is a significant relationship between rice technology adopters' income gained from rice production $(r=0.482, p=0,000)$ and their welfare status. There is also a significant relationship between these two variables among non-adopters $(r=0.325, p=0.008)$. This implies that the income derived from rice production has an influence on level of both of adopters and nonadopters' welfare. The result is a further indication that rice farming activities especially improved rice variety cultivation leads to a significant improvement in the rice farmers' income and bringing about reduction of poverty among the farming households in the study area. This is consistent with Bola, Taiwo and Aliou (2012) who identified rice production as an important crop with capacity to fight food security and poverty in most rural communities of the sub-Saharan African countries.

\section{Relationship Between Adopters Adoption Status, Quantity of Rice Produced and Welfare Status}

The result further reveals that there was significant relationship $(r=342, p=0.018)$ between adopters' welfare status and adoption of rice technologies in the study area, as presented in Table. This is in line with the proposition that adoption of improved technology will lead to increase in rice yield, profitability of rice production enterprise and improved household welfare of rice farmers. The study also establishes a significant relationship between respondents' crop yield $(r=0.230, p=0.024)$ and their welfare status. This is an indication that the higher the yield, the higher the welfare status of the respondents. That is, the improved yield achieved by the adoption of the technology has been able to achieve improved profitability, establishing a strong linear relationship between crop yield and welfare. This suggests that farmers had less of constraints getting customers to patronize the improved rice varieties that accompanied the improved rice technologies adopted. This finding is consistent with Omonona, Oni and Uwagboe (2006) and Amao and Awoyemi (2009) which established a strong and positive relationship between crop yield and farmers' welfare in Nigeria. 


\section{Difference between Adopters and Non-Adopters IN Level of Rice Production and Welfare Status}

Table 5 reveals that there was a significant difference $(t=-12.089, p=0.00)$ in the level of rice production of adopters and non-adopters of rice technology. This shows that the rice production level of Office du Niger rice technology adopters is higher than that of those who did not adopt the rice technology. The support services included double season rice cultivation due to the presence of small dams, production inputs subsidy packaged into the technology adoption programme, and other incentives which are not accessible to the non-adopters.

Table 5 also presents the result of the test of difference between the welfare status of adopters and non-adopters of rice technologies disseminated by Office du Niger. The results indicated in the Table 8 reveals that there is a significant difference $(\mathrm{t}=$ 2.917, $p=0.004)$ in the welfare status of the two categories of respondents. This demonstrates that the welfare status of the adopter of rice technology is higher $(1281790.8759$ FCFA) than that non-adopters (1037750.00 FCFA) of the technologies. This finding is in agreement with Minten and Barrett (2008) who argued that improved welfare, as an extension of improved productivity and income benefits can be guaranteed among poor households of developing countries only if improved agricultural technologies are adopted by a significant proportion of farmers.

Table 5: Differences in level of rice production between adopter and nonadopters

\begin{tabular}{|c|c|c|c|c|c|}
\hline Group & $\mathbf{N}$ & Mean & SD & $t$ & Df \\
\hline $\begin{array}{l}\text { Output } \\
\text { Adopters }\end{array}$ & 137 & 38544.73 & 17721.70 & -12.09 & 200 \\
\hline $\begin{array}{l}\text { Non adopters } \\
\text { Welfare }\end{array}$ & 65 & $\begin{array}{l}11394.77 \\
1281790.8\end{array}$ & 11394.77 & & \\
\hline Adopters & 137 & $\begin{array}{l}8 \\
1037750.0\end{array}$ & 525400.62 & -2.92 & 200 \\
\hline Non-adopters & 65 & 0 & 614462.88 & & \\
\hline
\end{tabular}

\section{${ }^{*} \mathrm{P} \leq 0.05$}

\section{Conclusion and Recommendation}

Adoption of rice production technologies disseminated by Office Du Niger contributed positively to the welfare status of the farmers. The study also concludes that improved welfare is a direct consequence of adoption of rice technologies disseminated by office du Niger

Dissemination of rice production technologies should not only be limited to the Office du Niger region, but it should be extended beyond the present catchment area so as to avail the farmers of the benefits inherent in the adoption of the technologies;

The government of Mail should also make sure that expanding the coverage area of dissemination of technologies is backed up with strategic plans to make market available for expected increase in rice output. This may be in the form of linking farmers to international markets so as to be able to guarantee good turnover and improved household welfare of rice farmers. 


\section{References}

African Development Bank Group (2014). Multinational: New Rice for Africa (NERICA) Dissemination Project, U.S. Department of the Treasury MDB awards. Retrieved October 20 , 2016

from https://www.afdb.org/fileadmin/uploads/afdb/Documents/Project-andOperations/Multinational- New Rice for Africa NERI

Amao J.O. Awoyemi T.T., Omonona B.T. and Falusi A.O. (2009). Determinants of poverty among fish farming households in Osun State, Nigeria. International Journal of Agricultural Economics and Rural Development, 2(2): 14-25.

Awotide, B. A. Awoyemi, T. T. and Diagne, A. (2012). Access to Certified, Improved Rice Seed and Farmers' Income in Nigeria. Journal of Crop Improvement, 26 (4): 558-579.

Baris, P., Z., J. and Perrin, S. (2005). Document of work, Rice in Mali: Market competiveness and perspectives. French Agent for Development. P. 19

Blaise W. B. (2016) : Impact de l'adoption des variétés améliorées de riz SAHEL sur la pauvreté au Sénégal : Approche de l'effet marginal du traitement (EMT). Retrieved September 05, 2016 from http://www.ecoasso.org/articles/Blaise Waly BASSE.pdf.

Bob T. (2014). One in Five African Adults Work on Farms. World Print. Retrieved 20 July 2017 from http://www.gallup.com/poll/168593/one-five-african-adults-work-farms.aspx.

Dawe, D. (2000): The contribution of rice research to poverty alleviation, Article in Studies, in Plant Science. Retrieved $8^{\text {th }}$ August, 2017 from DOI: 10.1016/S09283420(00)80003-8.

Food and Agriculture Organisation (2012). FAOSTAT. Food and Agriculture Organization of the United Nations. Retrieved August 07, 2016 from http://faostat.fao.org/default.aspx.

Gustavo A. and Kostas Stamoulis (2007). Rural Development and Poverty Reduction: Is Agriculture Still the Key? ESA Working Paper No. 07-02. Agricultural Development Economics Division. The Food and Agriculture Organization of the United Nations.

Mali's Ministry of Agriculture (2016). Bilan de la campagne agropastorale et halieutique : Résultats provisoires de la champagne.

Minten B, Barrett CB (2008) Agricultural technology, productivity, and poverty in Madagascar. World Dev, 36(5):797-82.

Minister of Agriculture of Mali (2009): National strategy for the development of rice growing.

Moussa, D., Amadou, K., and Alfousseyni, D (2012). Agricultural investments and land acquisitions in Mali: Context, trends and case studies.

OMICS International (2014). Open Access Articles- Top Results for FAO. Retrieved 10 January 2017 from http://research.omicsgroup.org/index.php/FAO.

Omonona, B.T., Oni, O.A., And Uwagboe, A.O. (2006) Adoption of Improved Cassava Varieties And Its Welfare Impact On Rural Farming Households In Edo State Of Nigeria. Journal of Agricultural and Food Information, 7(1): 39-55. 
Creative commons User License: CC BY-NC-ND

Abstracted by: EBSCOhost, Electronic Journals Service (EJS),

Google Scholar, Journal Seek, Scientific Commons,

Food and Agricultural Organization (FAO), CABI and Scopus
Journal of Agricultural Extension

Vol. 22 (3) October, 2018

ISSN(e): 24086851; ISSN(Print); 1119944X

http://journal.aesonnigeria.org

http://www.ajol.info/index.php/iae

Email: editorinchief@aesonnigeria.org

Sullumbe IM (2004). Resources use efficiency in cotton production under sole cropping system in Adamawa State of Nigeria. A Dissertation submitted to the school of Post graduate studies Maiduguri, Nigeria.

Vandersypen, K., Keita, A., Coulibaly, B., Raes, D. and Jamin, J. (2007). Drainage problems in the rice schemes of the Office du Niger (Mali) in relation to water management. Agricultural Water Management, 89:(2007) 153-160.

West Africa Agricultural Productivity Program (2014): A Major Boost for Agriculture in Mali. Retrieved October 05 , 2015 from http://www.worldbank.org/en/news/feature/2014/11/10/the-west-africa-agriculturalproductivity-program-a-major-boost-for-agriculture-in-mali

World-Grain Staff (2016): Rice is king in west and central Africa. The Grain and Grain Processing Information Site. Retrieved December 15, 2016 from http://www.worldgrain.com/articles/news home/Features/2016/01/Rice is king in w est and centr.aspx?ID=\%7B644CFE73-DA23-4E1B-A810-88E7C2430195\%7D. 